University of Nebraska - Lincoln

DigitalCommons@University of Nebraska - Lincoln

Publications from USDA-ARS / UNL Faculty

U.S. Department of Agriculture: Agricultural

Research Service, Lincoln, Nebraska

2012

\title{
Transcriptome and gene expression analysis in cold-acclimated guayule (Parthenium argentatum) rubber-producing tissue
}

\author{
Grisel Ponciano \\ USDA-ARS, grisel.ponciano@ars.usda.gov \\ Colleen M. McMahan \\ USDA-ARS \\ Wenshuang Xie \\ USDA-ARS, xie.184@osu.edu \\ Gerard R. Lazo \\ USDA-ARS \\ Terry A. Coffelt \\ USDA-ARS, terry.coffelt@ars.usda.gov
}

See next page for additional authors

Follow this and additional works at: https://digitalcommons.unl.edu/usdaarsfacpub

Part of the Agricultural Science Commons

Ponciano, Grisel; McMahan, Colleen M.; Xie, Wenshuang; Lazo, Gerard R.; Coffelt, Terry A.; Collins-Silva, Jillian; Nural-Taban, Aise; Gollery, Martin; Shintani, David K.; and Whalen, Maureen C., "Transcriptome and gene expression analysis in cold-acclimated guayule (Parthenium argentatum) rubber-producing tissue" (2012). Publications from USDA-ARS / UNL Faculty. 872.

https://digitalcommons.unl.edu/usdaarsfacpub/872

This Article is brought to you for free and open access by the U.S. Department of Agriculture: Agricultural Research Service, Lincoln, Nebraska at DigitalCommons@University of Nebraska - Lincoln. It has been accepted for inclusion in Publications from USDA-ARS / UNL Faculty by an authorized administrator of DigitalCommons@University of Nebraska - Lincoln. 


\section{Authors}

Grisel Ponciano, Colleen M. McMahan, Wenshuang Xie, Gerard R. Lazo, Terry A. Coffelt, Jillian CollinsSilva, Aise Nural-Taban, Martin Gollery, David K. Shintani, and Maureen C. Whalen 


\title{
Transcriptome and gene expression analysis in cold-acclimated guayule (Parthenium argentatum) rubber-producing tissue
}

\author{
Grisel Ponciano $^{a}$, Colleen M. McMahan ${ }^{a, *}$, Wenshuang Xie ${ }^{a, 1}$, Gerard R. Lazo $^{\text {a }}$, Terry A. Coffelt ${ }^{b}$, \\ Jillian Collins-Silva ${ }^{c, 2}$, Aise Nural-Taban ${ }^{c}$, Martin Gollery ${ }^{c, 3}$, David K. Shintani ${ }^{c}$, Maureen C. Whalen ${ }^{\text {a }}$ \\ ${ }^{a}$ USDA-ARS, Western Regional Research Center, 800 Buchanan Street, Albany, CA 94710, USA \\ ${ }^{\mathrm{b}}$ USDA-ARS, U.S. Arid-Land Agricultural Research Center, 21881 North Cardon Lane, Maricopa, AZ 85239, USA \\ c University of Nevada, Department of Biochemistry and Molecular Biology, Mailstop 330, Reno, NV 89557, USA
}

\section{A R T I C L E I N F O}

\section{Article history:}

Received 6 October 2011

Received in revised form 2 March 2012

Available online 17 May 2012

\section{Keywords:}

Parthenium argentatum

Guayule

Transcriptome

Natural rubber

Rubber transferase activity

Gene expression

\begin{abstract}
A B S T R A C T
Natural rubber biosynthesis in guayule (Parthenium argentatum Gray) is associated with moderately cold night temperatures. To begin to dissect the molecular events triggered by cold temperatures that govern rubber synthesis induction in guayule, the transcriptome of bark tissue, where rubber is produced, was investigated. A total of 11,748 quality expressed sequence tags (ESTs) were obtained. The vast majority of ESTs encoded proteins that are similar to stress-related proteins, whereas those encoding rubber biosynthesis-related proteins comprised just over one percent of the ESTs. Sequence information derived from the ESTs was used to design primers for quantitative analysis of the expression of genes that encode selected enzymes and proteins with potential impact on rubber biosynthesis in field-grown guayule plants, including 3-hydroxy-3-methylglutaryl-CoA synthase, 3-hydroxy-3-methylglutaryl-CoA reductase, farnesyl pyrophosphate synthase, squalene synthase, small rubber particle protein, allene oxide synthase, and cis-prenyl transferase. Gene expression was studied for field-grown plants during the normal course of seasonal variation in temperature (monthly average maximum $41.7^{\circ} \mathrm{C}$ to minimum $0{ }^{\circ} \mathrm{C}$, from November 2005 through March 2007) and rubber transferase enzymatic activity was also evaluated. Levels of gene expression did not correlate with air temperatures nor with rubber transferase activity. Interestingly, a sudden increase in night temperature 10 days before harvest took place in advance of the highest CPT gene expression level.
\end{abstract}

Published by Elsevier Ltd.

\section{Introduction}

Parthenium argentatum is a perennial shrub, commonly known as guayule, that is native to the Chihuahuan desert of northern Mexico and southwest Texas. Mature guayule plants produce high quality natural rubber in bark parenchyma tissue, mainly during winter when night temperatures are moderately cold, between 6 and $15^{\circ} \mathrm{C}$ (Bonner, 1943; Downes and Tonnet, 1985; Madhavan et al., 1989; Sundar and Reddy, 2000; Veatch-Bolhm et al., 2007; Benedict et al., 2010). The high quality of guayule rubber makes

\footnotetext{
* Corresponding author. Tel.: +1 510559 5816; fax: +1 5105595663.

E-mail addresses: grisel.ponciano@ars.usda.gov (G. Ponciano), Colleen.McMahan @ars.usda.gov (C.M. McMahan), xie.184@osu.edu (W. Xie), gerard.lazo@ars.usda. gov (G.R. Lazo), terry.coffelt@ars.usda.gov (T.A. Coffelt), jillian.collins@hotmail.com (J. Collins-Silva), marty.gollery@gmail.com (M. Gollery), shintani@unr.edu (D.K. Shintani), maureen.whalen@ars.usda.gov (M.C. Whalen).

1 Present address: Ohio State University, Department of Horticulture and Crop Science, 1680 Madison Ave., Wooster, OH 44691, USA.

2 Present address: University of Nebraska-Lincoln, Department of Biochemistry, 1901 Vine Street, Lincoln, NE 68588, USA.

${ }^{3}$ Present address: Tahoe Informatics, Incline Village, NV 89451, USA.
}

it amenable for industrial applications and is comparable to that produced by the rubber tree, Hevea brasiliensis (Cornish et al., 2008). As extracted, guayule latex also has the added benefit of lacking allergens in significant amounts to trigger Type I systemic allergies in humans (Hamilton and Cornish, 2010; Siler et al., 1996; Siler and Cornish, 1994a). Thus, the physical and chemical properties of guayule latex make it an attractive alternative material for the manufacture of medical and consumer products (Cornish et al., 2008).

Natural rubber is a cis-1,4-polyisoprene polymer synthesized by an as yet to be identified rubber transferase (E.C.2.5.1.20) enzyme in the cytosol of specialized cells. In Hevea, Taraxacum koksaghyz (Russian dandelion), and Ficus elastica (rubber fig) the specialized cells are laticifers (Gomez, 1982; Ko et al., 2003; Sando et al., 2009; Polhamus, 1962; Siler and Cornish, 1993; van Beilen and Poirier, 2007), whereas in guayule, the rubber-producing cells are parenchyma cells in the bark of stems and roots (Whitworth and Whitehead, 1991; Benedict et al., 2008). Biosynthesis of rubber takes place in lipidaceous monolayer vesicles referred to as 'rubber particles' starting with an allylic pyrophosphate initiator, such as farnesyl pyrophosphate (FPP), and continuing with progressive 
additions of isopentenyl pyrophosphate (IPP) molecules (Lynen and Henning, 1960; Tanaka, 2001; Cornish, 2001; van Beilen and Poirier, 2007). The initiator molecules as well as the IPP monomers are synthesized by the mevalonate pathway (MEV) in the cytosol of plant cells (Chappell, 1995; Cornish, 2001). Additionally, IPP and its isomer dimethyl allyl pyrophosphate (DMAPP) are synthesized in plastids via the 2-C-methyl-D-erythritol-4-phosphate (MEP) pathway (Sando et al., 2008; Cornish, 2001).

Proteins believed to be associated with guayule rubber particles include allene oxide synthase (AOS; Pan et al., 1995; Backhaus et al., 1991), cis-prenyl transferase (CPT), a putative component of rubber transferase (Cornish, 2001; Cornish and Backhaus, 2003), and small rubber particle protein (SRPP; also known as guayule homolog of SRPP [GHS]; Kim et al., 2004). The precise role of the three proteins in rubber biosynthesis in vivo is not yet known. Because rubber synthesis in guayule is temperature-dependent, with highest accumulation in the cold winter months (Cornish and Backhaus, 2003; Benedict et al., 2008), it is important to dissect the effect of cold temperature on this biosynthetic pathway. Understanding the regulation of rubber biosynthesis in guayule is critical to realize the goal of improving guayule as a domestic rubber crop, by means of breeding or genetic engineering, to achieve high yields of natural rubber.

To begin to understand the molecular basis of cold-induced rubber production in guayule, the gene expression profile was analyzed in an expression library from cold-acclimated guayule bark. In field-grown plants during the normal course of seasonal variation in temperature, the rubber transferase enzymatic activity and the expression profiles of genes associated with rubber synthesis were determined.

\section{Results and discussion}

\subsection{Analysis of cold-acclimated guayule EST population}

The stem parenchyma tissue is the main site of abundant rubber biosynthesis in mature guayule shrubs exposed to low night temperatures (Bonner, 1943; Goss et al., 1984; Jasso de Rodriguez et al., 2006), and thus a cDNA library was created from this tissue of a field-grown cold-acclimated plant. A total of 12,682 sequences were generated by randomly sequencing clones from this cDNA library (Table 1). The estimated average length of sequence was 600 bases. After quality editing and removal of vector sequences, a total of 11,748 quality sequences was obtained. There were 9021 unique transcripts (unigenes) that were generated from 3154 contigs and 5867 singletons (Table 1). About 5\% of the total ESTs in the normal-

Table 1

Analysis of guayule cold acclimated bark EST sequences.

\begin{tabular}{llr}
\hline & No. & $\%^{\mathrm{a}}$ \\
\hline Total raw sequences & 12,682 & \\
Total quality sequences & 11,748 & \\
Clustering analysis & & \\
$\quad$ Contigs & 3154 & 68 \\
$\quad$ Singlets & 5867 & 5 \\
Unigenes $^{\mathrm{b}}$ & 9021 & \\
High copy number ESTs & & 62 \\
Functional analysis & & 38 \\
$\quad$ Molecular function match & \\
$\quad$ Without molecular function match & 7279 & 59 \\
$\quad$ Biological process match & 4469 & 54 \\
$\quad$ Cellular component match & 6873 & 6329 \\
\hline
\end{tabular}

a Percent calculated from a total of 11,748 quality sequences.

b Number of unique transcripts is the total of contigs and singlets.

c GO match at level 1, 2, 3, or 4 .

d GO category with the most abundant GO terms. ized cDNA library were represented in the population at least five times and the frequency of ESTs ranged from 1 to 97 . Of the 11,748 sequences, $38 \%$ coded for proteins with unknown function. Of the proteins with known function, $62 \%, 59 \%$, and $54 \%$ could be classified as having molecular, biological and cellular functions, respectively.

Identities of the cold-acclimated guayule ESTs were assigned based on BlastX searches of the non-redundant NCBI database (Table 2). Guayule is native of a harsh desert ecosystem, so it is not surprising that several of the most abundant ESTs in our collection are related to stress responses, both abiotic and biotic. For example, the fourth most abundant EST encodes a protein that is similar to dehydrin, a protein known to be induced in response to low temperatures, drought, salinity, and hormonal treatment (Mingeot et al., 2009). Another EST encoded sequence identified as Erg-1, homologous to a superfamily of phosphate-induced proteins, is reported to be induced by pathogens, ethylene and salicylic acid in potato (Dellagi et al., 2000). Other stress response protein sequences encoded in the EST library include glutathione-S-transferase, an antioxidation enzyme (Marrs, 1996), S-adenosyl-Lmethionine synthase, and $S$-adenosylmethionine decarboxylase, both enzymes involved in polyamine synthesis. Polyamines are secondary metabolites with a role in regulation of cold, drought, and salt stress tolerance (Alcazar et al., 2010).

One interesting highly abundant transcript from our guayule EST population encodes aquaporin. In plants, aquaporins have numerous functions throughout growth and development, with complex functions in response to environmental cues (Maurel et al., 2008). In Hevea, two aquaporins that were differentially induced by hormonal treatments were shown to increase latex flow and concomitantly increase the latex yield (Tungngoen et al., 2010). Analysis of proteins from guayule rubber particles identified aquaporin peptides, as well (data not shown). It is possible that aquaporins may also play a role in guayule rubber production, but this remains to be determined. Another interesting EST in our collection encodes 1,2-beta-fructan 1F-fructosyltransferase, a fructan biosynthesis enzyme (Ritsema and Smeekens, 2003). Inulin, a fructan produced in guayule, is synthesized in high amounts during winter-like conditions and much less during warmer months (Kelly and van Stadem, 1994; Salvucci et al., 2010). In addition to serving as a reserve carbohydrate, fructans appear to have a role in the protection of plants during drought, salt, and cold stress as demonstrated in tobacco (Pilon-Smits et al., 1995). Although the molecular mechanism of these protective functions are not known yet, in vitro experiments with fructans and inulin established they interact with phospholipids, supporting the hypothesized role of preventing membrane damage caused by drought and cold stress (Demel et al., 1998; Vereyken et al., 2001). It is possible that inulin, besides acting as a storage carbohydrate, may stabilize rubber particles and thereby contribute to rubber production in the cold.

Three highly abundant, cold-acclimated guayule ESTs encoding polyubiquitin, cyclophilin, and a translationally-controlled tumor protein homolog (TCTP) are also reported to be present at high frequency in Hevea latex (Chow et al., 2007). Furthermore, an analysis of differentially regulated genes in Hevea during the onset of tapping panel dryness (TPD) syndrome, identified both polyubiquitin and cyclophilin among the up-regulated genes in TPD trees, whereas TCTP gene was significantly up-regulated in healthy trees (Venkatachalam et al., 2007). It is possible that both polyubiquitin, a protein involved in protein degradation, and cyclophilin, involved in protein folding, are acting to modulate protein composition in guayule during abiotic stress (i.e., cold) rather than having a direct role on rubber biosynthesis. As for TCTP, a highly conserved cytosolic calcium-binding protein found in all eukaryotes, several highly diverse functions in plants have been documented (Berkowitz et al., 2008; Aoki et al., 2005; Ermolayev et al., 2003; Brioudes 
Table 2

Putative identity of the most abundant guayule cold acclimated bark EST sequences.

\begin{tabular}{|c|c|c|c|c|}
\hline Protein match ${ }^{\mathrm{a}}$ & Species & Accession No. & No. of hits ${ }^{b}$ & Freq. $^{\mathrm{b}}(\%)$ \\
\hline Polyubiquitin & Oryza sativa & NP_001053957.1 & 92 & 1.0 \\
\hline Nucleic acid binding (DNA/RNA) & Arabidopsis thaliana & NP_180167.1 & 88 & 1.0 \\
\hline Transcription factor & Arabidopsis thaliana & NP_177117.2 & 74 & 0.8 \\
\hline Salicylic acid or methyl jasmonate responsive protein & Taraxacum officinale & ABA-27060.1 & 55 & 0.6 \\
\hline Aquaporin & Stevia rebaudiana & ABB88840.1 & 51 & 0.6 \\
\hline Glutathione S-transferase & Glycine max & AF243368.1 & 50 & 0.6 \\
\hline ATP binding protein kinase & Arabidopsis thaliana & NP_198447.2 & 45 & 0.5 \\
\hline Ubiquitin-conjugating enzyme & Nicotiana tabacum & BAB40310.1 & 43 & 0.5 \\
\hline Ubiquitin-protein ligase & Arabidopsis thaliana & NP_566274.1 & 40 & 0.4 \\
\hline $40 \mathrm{~S}$ ribosomal protein & Solanum tuberosum & ABA46777.1 & 38 & 0.4 \\
\hline $60 S$ ribosomal protein & Vitis riparia & Q9SPB3 & 34 & 0.4 \\
\hline Proteasome & Lactuca sativa & AAP72957.1 & 28 & 0.3 \\
\hline $21 \mathrm{kDa}$ protein precursor (Pectinesterase inhibitor) & Daucus carota & CAA36642 & 27 & 0.3 \\
\hline Putative nitrate transporter & Arabidopsis thaliana & AAM20651.1 & 26 & 0.3 \\
\hline Succinyl CoA ligase (alpha/beta subunit) & Solanum tuberosum & ABC01911.1 & 26 & 0.3 \\
\hline Stearoyl-ACP desaturase & Helianthus annuus & AAB65144.1 & 25 & 0.3 \\
\hline Glyceraldehyde 3-phosphate dehydrogenase & Daucus carota & AAR84410.2 & 24 & 0.3 \\
\hline Short-chain dehydrogenase/reductase & Lactuca sativa & BAE72097.1 & 22 & 0.2 \\
\hline Cytochrome P450 74A2 (allene oxide synthase, AOS/rubber particle protein, RPP) & Parthenium argentatum & Q40778 & 20 & 0.2 \\
\hline S-Adenosyl-L-methionine synthetase & Solanum tuberosum & ABB02634.1 & 20 & 0.2 \\
\hline DNA binding (zinc ion binding/AtSAP5) & Arabidopsis thaliana & NP_566429.1 & 19 & 0.2 \\
\hline Callus-expressing factor & Nicotiana tabacum & AAP40022.1 & 19 & 0.2 \\
\hline Prephenate dehydratase & Ipomoea trifida & AAS79603.1 & 18 & 0.2 \\
\hline Cyclophilin & Ricinus communis & CAC80550.1 & 18 & 0.2 \\
\hline S-Adenosylmethionine decarboxylase & Prunus persica & CAG28949.1 & 17 & 0.2 \\
\hline Protein phosphatase type $2 \mathrm{C}$ & Arabidopsis thaliana & NP_199989.1 & 16 & 0.2 \\
\hline 1,2-Beta-fructan $1 \mathrm{~F}$-fructosyltransferase & Helianthus tuberosus & CAA08811.1 & 15 & 0.2 \\
\hline Erg-1 (pathogen/ethylene/salicylic acid induced protein) & Solanum tuberosum & AAP42136.1 & 15 & 0.2 \\
\hline Translationally-controlled tumor protein homolog (TCTP) & Elaeis guineensis & Q5J907 & 15 & 0.2 \\
\hline Tubulin (alpha/beta chains) & Arabidopsis thaliana & BAE99023.1 & 15 & 0.2 \\
\hline Calmodulin 4 & Daucus carota & AAQ63461.1 & 15 & 0.2 \\
\hline Protein kinase & Arabidopsis thaliana & NP_564584.1 & 15 & 0.2 \\
\hline Transporter (SEC14 cytosolic factor/phosphoglyceride transfer) & Arabidopsis thaliana & NP_190735.1 & 15 & 0.2 \\
\hline
\end{tabular}

a Best BLAST hit in conceptually translated EST population with $P<10 \mathrm{e}^{-10}$.

b Number of hits and frequency in guayule bark EST population with 9021 unique sequences.

et al., 2010), none of which apparently relate to rubber production. Given the diverse functions of TCTP, the significance of its expression in guayule cold-acclimated tissue and in Hevea latex remains to be determined.

\subsection{Isoprenoid pathway and rubber biosynthesis related transcripts in cold-acclimated guayule}

Upon further mining of the EST population, all the genes encoding the enzymes of the MEV and MEP pathways were identified (Table 3). The chain propagation monomer IPP and its isomer, DMAPP are synthesized by the cytosolic MEV or the plastidic MEP pathways. In Hevea, high expression of the MEP pathway genes in latex and laticifers has been reported, suggesting that IPP derived from this pathway may also be involved in rubber synthesis (Chow et al., 2007; Ko et al., 2003). Feeding experiments, however, with ${ }^{13} \mathrm{C}$-mevalonate (an MEV pathway substrate) and with ${ }^{13} \mathrm{C}$-1-deoxy-D-xylulose (an MEP pathway substrate) concluded that in Hevea, rubber is synthesized from the MEV and not from the MEP pathway (Sando et al., 2008). The role of the MEP versus MEV pathways in supplying substrate for rubber synthesis in guayule has not been studied.

Among the MEV pathway enzymes, 3-hydroxy-3-methylglutaryl coenzyme A synthase (HMGS) and 3-hydroxy-3-methylglutaryl coenzyme A reductase (HMGR) are the ones best characterized in animal and plant model systems. In Hevea, a positive correlation between HMGS activity and dried rubber content of latex has been shown (Sirinupong et al., 2005). HMGR is considered to be the key regulatory step in IPP synthesis in the cytosol (Bach, 1986). In guayule, HMGR activity tracked with rubber transferase activity, both increasing with exposure to cold temperature, corresponding to a rapid increase in rubber formation (Ji et al., 1993), and in Hevea, HMGR1 was involved in rubber biosynthesis (Chye et al., 1992). The guayule transcriptome analysis, as in Hevea, show both HMGS and HMGR are encoded by a multigene family (Table 3; Chye et al., 1992; Sirinupong et al., 2005; Nagegowda et al., 2005; Dai et al., 2011; Ji et al., 1993).

In addition to the protein sequences described above, transcripts encoding other isoprenoid pathway enzymes of interest are represented in our cold-acclimated guayule ESTs, such as homologs of the enzymes geranyl diphosphate synthase (GPPS) and squalene synthase (SQS). Like natural rubber, isoprenoids such as terpenes are also synthesized by condensation reactions of IPP and FPP. GPPS synthesis of monoterpenes and SQS synthesis of triterpenes, for example, make use of the same cytosolic pool of IPP as rubber biosynthesis.

Transcripts encoding other proteins related to rubber biosynthesis (Table 3) were identified in guayule using the Hevea sequences for comparison, including farnesyl pyrophosphate synthase (FPPS), which synthesizes FPP, an initiator of rubber biosynthesis both in vivo and in vitro (Tanaka et al., 1996; Castillon and Cornish, 1999; Mau et al., 2003). Another Hevea protein homo$\log$ identified in our EST-deduced protein sequences, although not at as high abundance as in Hevea, is SRPP. A guayule SRPP homolog has been cloned and sequenced (Kim et al., 2004). Our guayule EST encodes an SRPP homolog that shares $99.9 \%$ amino acid identity to the previously isolated guayule protein, and approximately $60 \%$ similarity to the Hevea SRPP at the amino acid level. Purified recombinant guayule SRPP was shown to contribute to IPP incorporation during in vitro rubber biosynthesis (Kim et al., 2004). In transgenic Russian dandelion plants, suppression of SRPP decreases natural rubber content and rubber quality in roots (D. Shin- 
Table 3

Isoprenoid and rubber biosynthesis pathway genes present in cold-acclimated guayule EST population.

\begin{tabular}{|c|c|c|c|c|}
\hline Protein match ${ }^{\mathrm{a}}$ & Species & Accession No. & No. of hits ${ }^{b}$ & Freq. ${ }^{\mathrm{b}}(\%)$ \\
\hline \multicolumn{5}{|l|}{ Mevalonate (MEV) pathway } \\
\hline Acetoacetyl CoA thiolase & Helianthus annuus & AAQ77242.1 & 16 & 0.18 \\
\hline 3-Hydroxy-3-methylglutaryl coenzyme A synthase & Hevea brasiliensis & AAS46245.1 & 5 & 0.06 \\
\hline 3-Hydroxy-3-methylglutaryl coenzyme A reductase & Atractylodes lancea & ABK88909.1 & 2 & 0.02 \\
\hline Mevalonate kinase & Hevea brasiliensis & AF429384_1 & 3 & 0.03 \\
\hline Phosphomevalonate kinase & Hevea brasiliensis & AF429385_1 & 1 & 0.01 \\
\hline Mevalonate disphosphate decarboxylase & Hevea brasiliensis & AF429386_1 & 5 & 0.06 \\
\hline Isopentenyl pyrophosphate isomerase & Gentiana lutea & BAE92732.1 & 3 & 0.03 \\
\hline \multicolumn{5}{|l|}{ 2-C-Methyl-D-erythritol-4-phosphate (MEP) pathway } \\
\hline 1-Deoxy-D-xylulose 5-phosphate synthase & Tagetes erecta & AAG10432.1 & 3 & 0.03 \\
\hline 1-Deoxy-D-xylulose 5-phosphate reductoisomerase & Camptotheca acuminata & ABC86579.1 & 2 & 0.02 \\
\hline 4-Diphosphocytidyl-2-C-methyl-D-erythritol synthase ${ }^{\mathrm{c}}$ & Stevia rebaudiana & ABB88837.2 & 1 & 0.01 \\
\hline 4-Diphosphocytidyl-2-C-methyl-D-erythritol kinase & Stevia rebaudiana & ABB88838.2 & 2 & 0.02 \\
\hline 2-C-Methyl-D-erythritol 2,4-cyclodiphosphate synthase & Stevia rebaudiana & ABG23395.1 & 4 & 0.04 \\
\hline (E)-4-Hydroxy-3-methylbut-2-enyl diphosphate synthase & Stevia rebaudiana & ABG75916.2 & 5 & 0.06 \\
\hline (E)-4-Hydroxy-3-methylbut-2-enyl diphosphate reductase ${ }^{d}$ & Hevea brasiliensis & BAF98297.1 & 4 & 0.04 \\
\hline \multicolumn{5}{|l|}{ Rubber biosynthesis associated } \\
\hline Farnesyl pyrophosphate synthase & Parthenium argentatum & CAA57892 & 1 & 0.01 \\
\hline Small rubber particle protein & Parthenium argentatum & AAQ11374.1 & 7 & 0.08 \\
\hline Cytochrome P450 74A2 (allene oxide synthase) & Parthenium argentatum & Q40778 & 20 & 0.22 \\
\hline cis-Prenyltransferase & Hevea brasiliensis & AAR88763.1 & 4 & 0.04 \\
\hline \multicolumn{5}{|l|}{ Selected terpenoids pathway } \\
\hline IPP/DMAPP synthase & Stevia rebaudiana & ABB88836.2 & 8 & 0.09 \\
\hline Geranyl diphosphate synthase small subunit & Mentha $\times$ piperita & AF182827_1 & 9 & 0.10 \\
\hline Squalene synthase & Artemisia annua & AAR20328.1 & 5 & 0.06 \\
\hline
\end{tabular}

a Best BLAST hit in conceptually translated EST population with $P<10 \mathrm{e}^{-10}$

b Number of hits and frequency in guayule bark EST population with 9021 unique sequences.

c Also known as 4-diphosphocytidyl-2-methyl-D-erythritol synthase.

d Also known as 4-hydroxy-3-methylbut-2-en-1-yl diphosphate reductase.

tani, personal communication). Interestingly, a pepper (Capsicum annuum) SRPP ortholog over-expressed in Arabidopsis thaliana resulted in increased cell cycle progression leading to fast-growing plants; further, it appears to have a role in drought stress tolerance (Kim et al., 2010). Whether these biological functions of the C. annuum SRPP ortholog identified in Arabidopsis could be taking place in guayule remains to be tested.

The most abundant protein within the rubber particle of guayule, but not of Hevea, is a member of the CYP74 family of cytochromes P450 (Q40778), also known as allene oxide synthase (AOS; Pan et al., 1995) and originally identified as rubber particle protein (RPP; Backhaus et al., 1991). In accordance with the high protein levels, our cold-acclimated guayule EST collection was enriched with AOS transcript (Table 2). The function of AOS in guayule still remains to be determined, but it has been hypothesized to be either involved, directly or indirectly, in rubber biosynthesis (Siler and Cornish, 1994b), or to have a structural role within the rubber particle (Pan et al., 1995). AOS activity of isolated guayule rubber particles analyzed by Pan and co-workers resulted in enzymatic conversion of lipid hydroperoxide into its corresponding allene epoxide. The high abundance of active AOS in guayule rubber particles, together with the presence of high levels of hydroxy fatty acids (substrates of AOS) found in the glycolipid fraction of rubber particles (Siler et al., 1997), is suggestive of AOS role in lipid modification within the rubber particle.

Finally, four CPT-like deduced protein sequences similar to a Hevea CPT (AAR88763.1) were identified in our EST collection. Of the two cloned Hevea CPTs, only one exhibits in vitro rubber transferase activity; it was able to synthesize medium chain polyisoprenes ( 2000-10 $4 \mathrm{Da})$ (Asawatreratanakul et al., 2003). Three CPTs have been recently cloned from Russian dandelion (Schmidt et al., 2010a) and although all are functional enzymes (Schmidt et al., 2010b), their rubber transferase activity remains to be determined. CPTs are enzymes that synthesize various types of isoprenoids, have been identified in both prokaryotes and eukaryotes, and their primary structures have five highly conserved regions (Regions I-V; Kharel and Koyama, 2003). Amino acid changes within, or near, the conserved regions appear to be important in determining the length of the prenyl chain product CPT enzymes' synthesize (Kharel et al., 2006). Guayule CPT-like sequences, as well as all Hevea and Russian dandelion CPTs, lack the conserved amino acid sequences characteristic of CPTs that synthesize short-chain products (i.e., $\mathrm{C}_{15}$ ). Further, guayule CPTs lack a putative N-terminus membrane-spanning motif present in both cloned Hevea CPTs (Asawatreratanakul et al., 2003), as is the case for Russian dandelion. Based on protein sequence homology alone therefore, it is not possible to determine which guayule CPT-like sequence is specifically involved in rubber synthesis. Interestingly, transcript levels of CPT in EST collections from Hevea appear to be low or altogether absent (Han et al., 2000; Ko et al., 2003; Chow et al., 2007). Similarly, the transcript encoding CPT in our coldacclimated guayule EST collection was not very abundant (Table 3).

Altogether, transcripts of enzymes relevant to rubber biosynthesis constituted about $1.1 \%$ of our guayule unigene population.

\subsection{Expression profile of genes relevant to rubber biosynthesis in field- grown guayule}

There is a well-established negative correlation between temperature and rubber transferase activity and/or rubber accumulation in guayule; that is, cold temperatures induce higher rubber transferase activity (Table 4; Cornish and Backhaus, 2003; Ji et al., 1993) and increase rubber production (Salvucci et al., 2010; Veatch-Bolhm et al., 2007). In this study, in vitro rubber transferase activity in rubber particles harvested from plants between November 2005 and March 2007 showed the expected higher activity during periods of cold night temperature, and the lowest enzyme activity during the warmer months (Table 4). The average night temperature for the harvest date is included in Table 4 for reference; cold induction of rubber biosynthesis takes place over 
Table 4

Rubber transferase activity in field-grown guayule plants.

\begin{tabular}{lll}
\hline $\begin{array}{l}\text { Average night temperature } \\
\left({ }^{\circ} \mathrm{C}\right)\end{array}$ & $\begin{array}{l}\text { Harvest } \\
\text { date }\end{array}$ & $\begin{array}{l}\text { Rubber transferase activity } \\
( \pm \text { s.e. })\end{array}$ \\
\hline $\begin{array}{l}\text { Cold } T \\
4.7\end{array}$ & $1 / 17 / 06$ & $2.70( \pm 0.254)$ \\
5.3 & $1 / 17 / 07$ & $4.04( \pm 0.516)$ \\
9.8 & $12 / 13 / 05$ & $2.84( \pm 0.047)$ \\
13 & $2 / 17 / 06$ & $3.61( \pm 0.241)$ \\
13.9 & $2 / 12 / 07$ & $1.87( \pm 0.209)$ \\
14.3 & $11 / 3 / 06$ & $1.12( \pm 0.066)$ \\
15.9 & $11 / 15 / 05$ & $8.96( \pm 0.066)$ \\
16.7 & $12 / 8 / 06$ & $5.69( \pm 0.165)$ \\
17.6 & $3 / 12 / 07$ & $3.90( \pm 0.042)$ \\
Warm $T$ & & \\
25.5 & $10 / 3 / 06$ & $0.52( \pm 0.074)$ \\
27.1 & $5 / 15 / 06$ & $0.22( \pm 0.005)$ \\
35.5 & $6 / 5 / 06$ & $0.21( \pm 0.047)$ \\
\hline
\end{tabular}

a Average night temperature before harvest day; data obtained from the Arizona Meteorological Network (http://ag.arizona.edu/azmet/index.html), Maricopa station.

${ }^{\mathrm{b}}$ Activity measured as $\left[{ }^{14} \mathrm{C}\right]$-IPP $(1 \mu \mathrm{M}$ unlabeled IPP, $0.9 \mathrm{nmol}$ labeled IPP, $15 \mu \mathrm{M}$ FPP) incorporation rates ( $\mu \mathrm{mol} / \mathrm{g}$ dry rubber) by enzymatically-active purified rubber particles extracted from stem tissue. Each value is the mean of three technical replicates \pm standard error.

a longer timescale than $24 \mathrm{~h}$. Shrubs harvested during warm (over $25^{\circ} \mathrm{C}$ ) temperatures consistently yielded low rubber transferase activity $(\sim 0.5 \mu \mathrm{mol} / \mathrm{g}$ dry rubber or less). However, the highest activity ( $8.96 \mu \mathrm{m} / \mathrm{g}$ dry rubber) was found in November 2005, following an average night temperature of $15.9{ }^{\circ} \mathrm{C}$. The lowest temperature harvest $\left(4.7^{\circ} \mathrm{C}\right.$, January 2006) yielded relatively moderate rubber transferase activity $(2.70 \mu \mathrm{m} / \mathrm{g}$ dry rubber $)$. Clearly there is not a simple correlation between rubber biosynthesis and temperature in a field environment. Many other factors, including but not limited to plant age, field position, rainfall, stress, and the cumulative time under low temperature, contribute to variation in rubber transferase activity. Even sampling of stems from different positions on the main stem of field grown plants can impact measured rubber transferase activity (Benedict et al., 2008). Despite the variation observed and lack of biological replicates, rubber transferase activity measured in plants harvested in the colder months of the years was consistently higher than the activity in plants harvested in the warmer months. Therefore, from the perspective of natural rubber biosynthesis, these plants are a representative series within the variation found in field growth and harvest conditions. Cold temperature requirements to stimulate rubber biosynthesis in guayule have been reported to be as low as $5^{\circ} \mathrm{C}$ and as high as $20^{\circ} \mathrm{C}$ (Bonner, 1943; Downes and Tonnet, 1985; Madhavan et al., 1989; Sundar and Reddy, 2000; Cornish and Backhaus, 2003; Veatch-Bolhm et al., 2007; Benedict et al., 2010). One reason for the wide range of cold temperature requirements could be due to differences in the guayule lines used in each experiment, and since guayule is still not a fully domesticated plant, substantial intra-line phenotypic variability exist. It is also important to keep in mind that rubber synthesis is age-dependent, thus, the plant developmental stage at which different experiments are performed may not be comparable across all experiments reported.

Our study documents the induction of rubber transferase activity in mature guayule plants in December, 2006. Plants sampled October 3, 2006 had relatively low activity $(0.52 \mu \mathrm{m} / \mathrm{g}$ dry rubber $)$. Over the next 31 days, average low temperatures were all below $20{ }^{\circ} \mathrm{C}$, but at or below $10^{\circ} \mathrm{C}$ on 11 days; measured rubber transferase activity by November 3 had more than doubled to $1.12 \mu \mathrm{m} / \mathrm{g}$ dry rubber. During the next 35 day period, average low temperatures were at or below $10^{\circ} \mathrm{C}$ every day and by December 8 activity had increased 5-fold to $5.69 \mu \mathrm{m} / \mathrm{g}$ dry rubber.
To determine the correlation between temperatures in the field and expression levels of genes encoding proteins involved in rubber biosynthesis, reverse transcriptase-quantitative PCR (RT-qPCR) analysis was performed on RNA extracted from plant tissue harvested in November-December 2005; January, February, May, June and October-December 2006, and January-March 2007. Transcript levels of all genes analyzed (HMGS, HMGR, FPPS, SQS, CPT, SRPP, and $A O S$ ) were quantified by comparing them to the levels of the corresponding gene in a calibrator plant (Supplementary Table 1). The calibrator plant was grown under the same field conditions, however, harvested at a different date with warmer temperatures, and therefore age differences between the experimental and calibrator shrubs exist. To minimize age differences in our analysis bark RNA was used only from harvested stems of approximately equal age; that is $10 \mathrm{~mm}$ diameter-segments of $4-5 \mathrm{~cm}$ length. To find meaningful trends, gene expression levels were analyzed as a function of: maximum and minimum day and night temperatures (at the time of harvest as well as up to 45 days before harvest), rate of change of minimum ambient temperature up to 45 days before harvest, hours below the $6-15{ }^{\circ} \mathrm{C}$ threshold temperature needed for rubber biosynthesis induction, and day length. It is noteworthy that the plant harvested in December 2005 showed unexpectedly low expression for all genes (Supplementary Table 1). Enzyme activity (Table 4) and metabolite levels (not shown) for this plant were as expected for a cold-induced shrub; therefore, the cause of the low expression is not known. RNA purity and integrity was monitored throughout the gene expression analysis for all genes, and thus the expression levels measured reflect the physiological status of each plant stem at the time of collection. The portion of stem tissue used as source of RNA for gene expression analysis was different from the stem used for the rubber transferase activity assay, although it was collected at the same time from the same plant.

No correlation of gene expression with air temperature the night before harvest, nor with temperature changes up to 45 days before harvest, were observed for all genes (not shown), with the exception of CPT (see Section 2). What was apparent is that as the season progressed into the cooler months (i.e., November 2006 through January 2007), expression of CPT and AOS increased, peaked (in December 2006 and January 2007, respectively), and decreased in February and March 2007 (Supplementary Table 1). Evidently, gene expression patterns of these genes were the result of a cold induction.

Analysis of variance was performed to examine the expression of the same genes at selected time points for which biological replicates were available (Table 5). This analysis established that transcript levels of HMGS, HMGR, SRPP, and CPT were significantly different $(P$-values $<0.05)$ among collection dates, but not those of AOS, FPPS, and SQS. The biological significance of the ANOVA analysis for HMGS and HMGR genes is difficult to dissect because the primer sets designed for gene expression were not generic, that is, the HMGS primers hybridized with three out of the five HMGS ESTs, and the HMGR primers hybridized with one of the two HMGR ESTs. Therefore, it is possible that the HMGS and HMGR genes not relevant for rubber biosynthesis were targeted. Whatever the role of the HMGS and HMGR genes that our primers did target, however, no correlation with rubber transferase activity nor with temperature was found for those genes (not shown). Interestingly, one of the two Hevea HMGS genes cloned exhibited a diurnal variation in mRNA accumulation that coincided with a diurnal variation in enzyme activity (Suwanmanee et al., 2004). Although diurnal variation in gene expression remains to be investigated in guayule, the HMGS gene expression data could reflect such phenomena. HMGR expression of field-grown guayule was previously analyzed by northern blot using a tomato HMGR-1 cDNA probe (Ji et al., 1993). In that study, a positive correlation was shown between 
Table 5

Analysis of variance of rubber synthesis-related gene expression levels in field-grown guayule plants.

\begin{tabular}{|c|c|c|c|c|c|c|c|}
\hline \multirow[t]{3}{*}{ Harvest date } & \multicolumn{7}{|c|}{ Relative gene expression $^{\mathrm{a}}$ ( \pm s.e.) } \\
\hline & \multicolumn{4}{|c|}{ Isoprenoid pathway genes } & \multicolumn{3}{|c|}{ Rubber particle associated genes } \\
\hline & HMGS & HMGR & FPPS & SQS & SRPP & AOS & CPT \\
\hline $12 / 8 / 06$ & $2.33( \pm 0.03)$ & $1.34( \pm 0.11)$ & $1.10( \pm 0.43)$ & $2.47( \pm 0.67)$ & $1.75( \pm 0.30)$ & $2.14( \pm 0.65)$ & $2.14( \pm 0.34)$ \\
\hline $1 / 17 / 07$ & $0.32( \pm 0.08)$ & $0.09( \pm 0.01)$ & $0.10( \pm 0.02)$ & $1.16( \pm 0.40)$ & $1.76( \pm 0.41)$ & $0.62( \pm 0.14)$ & $0.68( \pm 0.01)$ \\
\hline $3 / 12 / 07$ & $0.24( \pm 0.07)$ & $0.73( \pm 0.27)$ & $0.50( \pm 0.22)$ & $0.36( \pm 0.09)$ & $0.41( \pm 0.06)$ & $0.68( \pm 0.10)$ & $0.32( \pm 0.04)$ \\
\hline \multirow[t]{3}{*}{$2 / 12 / 07$} & $0.65( \pm 0.44)$ & $0.96( \pm 0.38)$ & $0.42( \pm 0.13)$ & $0.75( \pm 0.43)$ & $0.73( \pm 0.05)$ & $1.30( \pm 0.41)$ & $0.42( \pm 0.09)$ \\
\hline & \multicolumn{7}{|c|}{ ANOVA $P$-value } \\
\hline & 0.0006 & 0.035 & 0.111 & 0.418 & 0.011 & 0.084 & 0.0003 \\
\hline
\end{tabular}

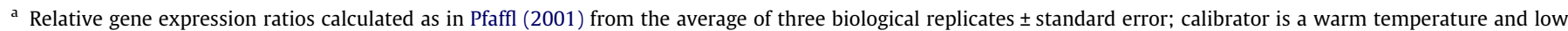
rubber transferase activity plant (Table 4 ) harvested on 10/3/06.

the number of accumulated hours of $5-7^{\circ} \mathrm{C}$ with rubber transferase and HMGR activity rates (increasingly higher activities of both enzymes as the number of hours of cold temperatures increase from October to December). Expression of HMGR in that study included microsomal, chloroplast, and mitochondrial activity, was high in November (attributed to rubber biosynthesis) but was also high in June, attributed to seedling growth. Isolation and characterization of all guayule HMGR gene family members is needed in order to in order to fully describe the expression patterns and requirements for the rubber biosynthesis-related HMGR.

It has been suggested that SRPP has a role of enhancing rubber biosynthetic activity. For example, recombinant guayule SRPP added to isolated Hevea rubber particles increased the molecular weight of the rubber produced in vitro (Kim et al., 2004). Additionally, immunogold labeling for detection of SRPP on the surface of isolated rubber particles of different plant species demonstrated the presence of SRPP only on those particles from the high molecular weight rubber producing plant Hevea, but was completely absent in the particles from the lower molecular weight rubber producing plants Ficus carica and Ficus benghalensis (Singh et al., 2003). If indeed SRPP is a rubber particle-associated protein as is believed, the fact that SRPP expression levels did not correlate with rubber transferase activity (Fig. 1) suggests that SRPP protein levels are regulated post-transcriptionally. Interestingly, a proteome analysis of cold- acclimated Helianthus annuus (sunflower) found

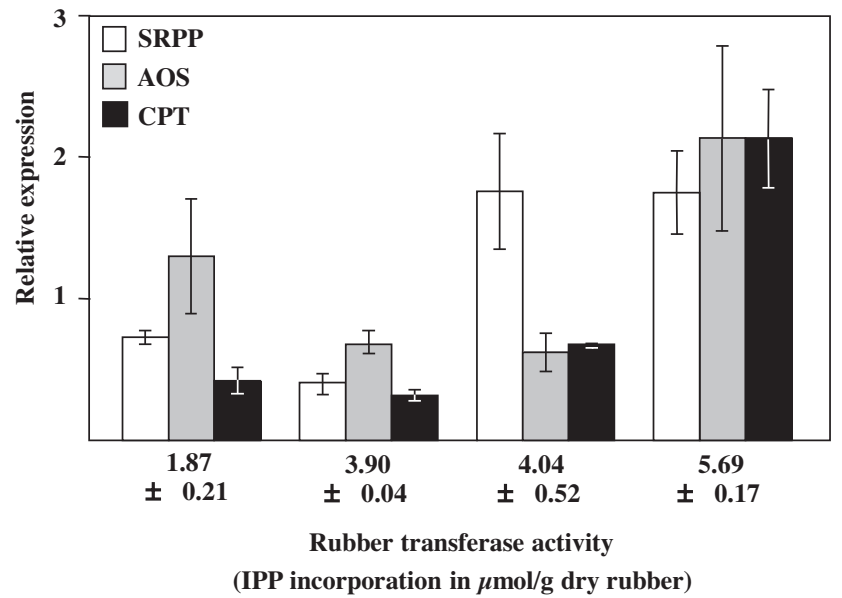

Fig. 1. SRPP, AOS, and CPT gene expression levels compared to rubber transferase activity in guayule. RNA from bark tissue from stems was the sample source for qRT-PCR analysis. Each data point is the average gene expression of three biological replicates (error bars represent the standard deviation error) calculated as in Pfaffl (2001) and relative to the $10 / 3 / 06$ calibrator plant. Rubber transferase activity measured as $\left[{ }^{14} \mathrm{C}\right]$-IPP incorporation rates ( $\mu \mathrm{mol} / \mathrm{g}$ dry rubber) by enzymaticallyactive purified rubber particles extracted from stem tissue. Each value is the mean of three technical replicates \pm standard error. an SRPP ortholog to be differentially expressed (Balbuena et al., 2011) supporting the possibility that in guayule SRPP post-transcriptional modification(s) may occur. Like in sunflower and pepper, it is possible that SRPP has a role in cold tolerance in guayule, or other unknown functions, which could have prevented detection of a cold induction in our gene expression analysis.

Rubber transferase activity within a $5-20^{\circ} \mathrm{C}$ night temperature range, although variable within this range, was higher than the activity when night temperatures were greater than $25^{\circ} \mathrm{C}$ (Table 4). The prenyl transferase function is tightly associated with rubber particles and thus it is reasonable to hypothesize that CPT may be a component of the in vivo rubber transferase enzymatic complex. The set of primers and probe designed for qPCR analysis of CPT detected all four guayule CPT-like gene sequences expressed in rubber-producing tissue. The finding that no positive correlation between CPT gene expression and rubber transferase activity was found (Fig. 1) indicates either (1) the regulation point of CPT is at the post-transcription level, or (2) CPT is not a critical component of this putative enzymatic complex, a possibility but not easy to dismiss since it is well established that the multiple IPP condensation reactions that form rubber are catalyzed by cis-prenyl transferase activity, such as that of a CPT. In a previous study, induction of rubber transferase activity by low temperatures in field-grown guayule plants was observed when night temperatures abruptly fell $42-$ 57 days before the enzyme activity abruptly increased (Cornish and Backhaus, 2003). In light of this, considering CPT a component of the rubber transferase enzymatic complex, daily night temperature changes up to 45 days were analyzed before harvest and association of the highest CPT expression levels with a fluctuation in night temperature 9-11 days before harvest was found (Fig. 2). In fact, the highest CPT expression level was measured when 11 days

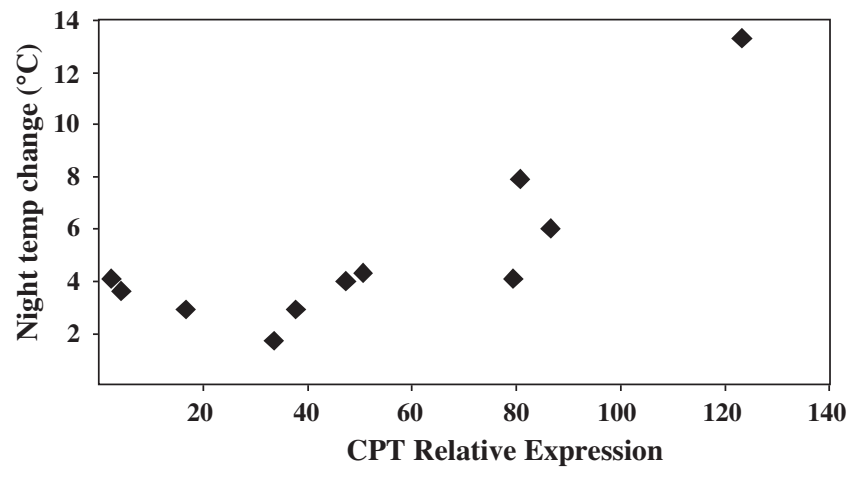

Fig. 2. Highest expression of $C P T$ occurs following change in night temperature 911 days before harvest. Temperature data obtained as indicated in Table 4 and changes calculated in $24 \mathrm{~h}$ intervals. RNA source and gene expression analysis performed as in Fig. 1, using a different calibrator plant (6/5/06 harvested plant, Supplementary Table 1). 
before harvest the minimum night temperature was $-1{ }^{\circ} \mathrm{C}$, increased to a $12.3^{\circ} \mathrm{C}$ temperature the next night ( 10 days before harvest), and decreased to a low $2.9^{\circ} \mathrm{C}$ temperature the following night ( 9 days before harvest). Furthermore, statistical analysis demonstrated that the highest CPT expression level was significantly higher than the rest of the samples analyzed (Table 5). It is possible that the effect of a 9-11 day pre-harvest night temperature change on CPT gene expression was due to a signal induced by the cold temperatures that followed the sudden temperature increase. Although the nature of such cold inducible signal is yet to be found, our analysis indicates the presence of a putative cold-inducible CPT gene in guayule which, as a component of the rubber transferase complex, may account for the known requirement of cold night temperatures for rubber biosynthesis induction.

Gene expression of guayule AOS varied throughout the 20062007 winter months, but expression levels were not significantly correlated with rubber transferase activity (Fig. 1). Interestingly, there is evidence that guayule rubber particle-associated AOS is a glycoprotein (Backhaus et al., 1991), and glycosylation of AOS may be a regulatory step in the production of the active mature protein. Additionally, guayule AOS like other sub-family (CYP74A) members, in spite of lacking an N-terminal membrane anchor signal, remains associated with membranes during extraction procedures (Song and Brash, 1991; Pan et al., 1995; Hughes et al., 2006). It is possible then that a different type of membrane-binding domain, or a post-translational modification leads to membrane targeting of AOS because it appears that activity of all CYP74 enzymes in vivo requires membrane association (Hughes et al., 2009). Altogether, the above data indicate several plausible mechanisms of AOS regulation at the post-translational level rather than at the transcriptional level.

FPP is the precursor of many terpenoids in the cytosol of plants such as dolichols, sesquiterpenes, prenylated proteins, rubber, etc. Given the importance of FPP availability for synthesis of rubber and other terpenoids, one might expect to detect differences in expression levels of FPPS during cold months, but that was not the case as indicated by the analysis of variance (Table 5). Genes for two guayule FPPS (84\% identity at the nucleotide level, and 95\% identity at the deduced amino acid level) from stem bark have been cloned and their recombinant proteins were shown to produce FPP as the major product in vitro (Pan et al., 1996). Due to the high level of identity, our FPPS expression analysis did not discriminate between the two sequences, meaning that neither gene was induced by cold in field-grown plants. Transgenic FPPS-guayule plants grown in the field showed no significant difference in rubber yield compared to control plants; however, resin (composed mainly of terpenes) content increased significantly (Veatch et al., 2005). In our study, FPPS gene expression did not, however, correlate to resin accumulation (data not shown).

Another terpenoid synthesized from IPP is squalene (the precursor of triterpenes and sterols). Squalene is synthesized by the condensation of two molecules of FPP catalyzed by squalene synthase (SQS). Therefore, it was of interest to know the variation in transcript levels of SQS during the cold temperatures that stimulate rubber biosynthesis. No significant difference in gene expression levels was observed for SQS supported by the analysis of variance applied on the 2006-2007 winter samples (Table 5). Salvucci and coworkers analyzed guayule resin accumulation and production of volatile terpenoids and conclude that these metabolites are regulated differently from the accumulation of rubber (Salvucci et al., 2010).

\section{Conclusions}

In this report, the first analysis of the transcriptome of coldacclimated guayule is presented. Creation of our EST collection was motivated by the search for genes involved in rubber biosynthesis, including the elusive member(s) of the rubber transferase enzyme complex. It was found that cold-acclimated, rubber-producing guayule tissue is enriched with AOS transcript, but not much by other transcripts encoding proteins believed to be associated with rubber particles (e.g., CPT and SRPP), or the isoprenoid pathway enzymes that make the precursors for rubber biosynthesis (MEV enzymes and FPPS). Moreover, seasonal expression analysis of known and putative rubber biosynthesis-related genes from field-grown guayule shrubs found no cold-induction, except perhaps for CPT in which case a sudden increase in ambient temperature at night 10 days before harvest was associated with the highest expression level. Additionally, no positive correlation of expression levels for all genes with rubber transferase activity was found. These results conclude that either (1) gene expression is not controlling the enzymatic activity of the rubber transferase complex, but instead post-translational modifications are the point of control, or (2) proteins encoding the genes analyzed are not those regulating rubber biosynthesis, thus the critical member(s) of the rubber transferase complex are yet to be identified.

\section{Experimental}

\subsection{Plant materials}

Guayule ( $P$. argentatum AZ2) plants used for all experiments were grown in the field at the USDA-ARS Arid-Land Agricultural Research Center in Maricopa, Arizona. Stems used for the rubber transferase assay were different from those used for the gene expression analysis; however, all were harvested from the same shrub at each corresponding harvest date. The guayule shrub's age at the start of harvesting (November 2005) was 1-year old. Whole plants from a single field location were harvested, and shipped overnight on wet ice to the USDA-ARS Western Regional Research Center in Albany, California over a period of 17 months. Bark tissue from 10 to $15 \mathrm{~mm}$ diameter-stem segments of a single plant was processed immediately to isolate rubber particles or frozen in liq. $\mathrm{N}_{2}$ and then stored at $-80^{\circ} \mathrm{C}$ until used. Stems of similar diameter from a single shrub were defined as technical replicates (November 2005 to March 2007). In some cases, stems of similar diameter (10-15 mm) from multiple shrubs were harvested to produce biological replicates (October 2006, and December 2007 to March 2007).

\subsection{EST library construction and sequence analysis}

RNA from bark tissue of 10-15 mm-diameter stem segments of a 2 year-old guayule shrub was extracted using the Qiagen RNAEasy Plant Midi Kit (Qiagen USA). The integrity of the RNA samples was checked by PAGE gels prior to expression analysis, and the purity of all samples was confirmed spectrophotometrically. Pooled RNA from the extraction of four identical bark tissue samples (500 mg) was used for cDNA synthesis. A cDNA library was made from poly(A) selected mRNA. Poly(A) mRNA was converted to double-stranded cDNA by using a modified oligo(dT) primer (AACTGGAAGAATTCGCGGCCGCACCGATTTTTTTTTTTTTTT TTVN). The double-stranded cDNA was ligated to an EcoRI adaptor (AATTCCGTTGCGTCG) and the adaptored CDNA was size selected for fragments $>600$ bps. The cDNAs were then digested with NotI and EcoRI and ligated into the NotI/EcoRI sites of pBluescript II SK+. The resulting cDNA library contained $\sim 1.3 \times 10^{6}$ clones. Sequencing of the ESTs was done at the W.M. Keck Center for Comparative and Functional Genomics, University of Illinois, USA. Quality Read Lengths from sequences were extracted with Phred 
(Ewing et al., 1998) program. File trimming based on sequence mark-up done with Cross_match (http://www.phrap.org/phredphrap/general.html) program, minor vector/adaptor sequences remained.

The cold-acclimated bark tissue EST sequences were deposited in $\mathrm{dbEST}$ at the National Center for Biotechnology Information (NCBI) with accession numbers GW775573-GW787311 ESTs, and contigs were screened for similar sequences and translation products by BLAST comparison ( $E$ value of $<1.0 \mathrm{E}^{-04}$ ) with the following databases: dbEST and UniProt. Classification of function was performed using the Gene Ontology (GO) convention (Ashburner et al., 2000).

\subsection{Quantitative real time $R T-P C R$ analysis}

Bark tissue from three stems (10 mm diameter along a $4-5 \mathrm{~cm}$ segment) from one shrub, or from one stem on each of three shrubs, from field-grown shrubs was the source of total RNA $(2 \mu \mathrm{g})$ that was used as template for cDNAs using the SuperScript III First-Strand Synthesis System for Reverse Transcriptase (RT)PCR (Invitrogen, USA). Quantitative PCR (qPCR) on cDNAs of PaCPT, PaAOS, PaSRPP, PaHMGS, PaHMGR, PaFPPS, PaSQS, and PaEIF4A was carried out using Applied Biosystems 7500 Fast Real Time PCR System and the TaqMan ${ }^{\circledR}$ chemistry (Applied Biosystems, USA). To calculate mean relative expression levels of each guayule gene, cDNAs were analyzed in triplicate in the same 96-well micro chamber plate. All gene probe efficiencies and relative expression ratios were calculated according to Pfaffl (2001). Efficiencies were 1.99 for PaEIF4A, 2.00 for PaCPT, 1.96 for PaAOS, 1.93 for PaSRPP, 2.03 for PaHMGS, 2.07 for PaHMGR, 2.09 for PaFPPS, and 2.21 for PaSQS. Expression of each target gene was normalized to expression of the constitutively expressed endogenous reference gene PaEIF4A, and then to its expression in a calibrator (control sample of warm temperature grown shrubs with low levels of rubber transferase activity of either 0.21 or $0.52 \mu \mathrm{mol}$ IPP incorporated per gram of dry rubber [6/5/06 and 10/5/06 in Table 4, respectively]). qPCR runs for each target gene using the same RNA and newly synthesized cDNA were performed twice. The following combinations of forward/reverse primers and probes were used for the qPCRs: for PaCPT, 5'-GCTTCTTTTTCGGGTCATTTCA-3'/5'TGCCAAGAATCCGGCTTTAT- $3^{\prime}$, and probe 5'FAM-CGGCCCGATTCCACAACATATAGCATT-TAMRA3'; for PaAOS, 5'-CACGGTATTTCGAGC CAACA-3' $/ 5^{\prime}$-CGTCGAGTAGGACGATGACCTT-3', and probe $5^{\prime}$ FAMCCACCGGGCCCTTTCGTAAGCA-TAMRA3'; for PaSRPP 5'-GTGGCCA ACACATTGTACGTAAA-3' $/ 5^{\prime}$-TTCTCAGCTACCGGCTCGTAGT-3', and probe 5'FAM-TGCGAGCCAACAGCTAAACAGCTATACATGA-TAMRA3'; for PaHMGS 5'-GGTTCAGCCAGGAACTTTGG-3'/5'-GGAAGC AAATGCAGCATATAAAGA-3', and probe 5'FAM-CCC AAA CAA CTG GGA AAC ATG TAC ACT GC-TAMRA3'; for PaHMGR 5'-ATGGGCA TTTCTGGAAACTATTG-3'/5'-CTTCCCTCGCCCTTCTATCC-3', and probe 5'FAM-TCC GAC AAG AAA CCT GCG GCA ATA AAC-TAMRA3'; for PaFPPS 5'-TCAACGATCCTGCCTTCGA-3'/5'-TCCAGGTACGTTGTAGTCAAGCA-3', and probe 5'FAM-TTC GAC GAC GAC TCC CGT CAA TGG-TAMRA3'; for PaSQS 5'-GATCCCAATGCCACAACTACAA3'/5'-CCAGAGGCCTTGCATATTTTCT-3', and probe 5'FAM-TCC AGG ATT GAA GCA GCT-TAMRA3'; and for PaEIF4A 5'-TTGAATGCCAGGCTTTGGTT-3' $/ 5^{\prime}$-GCGCGCATGACCTTCTCA-3' and probe 5'FAM-ACCAACTCGTGAACTTGCGCAGCAA-TAMRA3'. TaqMan Fast Universal PCR Master Mix $(2 \times)$ and No AmpErase ${ }^{\circledR}$ UNG (Applied Biosystems, USA) were used in each qPCR in combination with $900 \mathrm{nM}$ each primer and $250 \mu \mathrm{M}$ TaqMan ${ }^{\circledR}$ probe with the following temperature regime: $95^{\circ} \mathrm{C}$ for $20 \mathrm{~s}$, followed by 40 cycles of $95^{\circ} \mathrm{C}$ for $3 \mathrm{~s}$ and $60^{\circ} \mathrm{C}$ for $30 \mathrm{~s}$. Data were analyzed using the 7500 Fast System Detection Software (Applied Biosystems, USA) with manually set baseline and threshold.

\subsection{In vitro assay of rubber synthesis}

Enzymatically-active rubber particles were extracted from bark tissue that was stored either on ice or at $4{ }^{\circ} \mathrm{C}$ after harvesting, and then processed within $96 \mathrm{~h}$ following Xie et al. (2008). Rubber transferase activity was measured mostly following the method described by Xie et al. (2008), modified from the original methods developed by Cornish and Backhaus (1990) and Mau et al. (2000). Briefly, IPP incorporation rates were measured using extracted rubber particles $(0.5 \mathrm{mg}), 1 \mathrm{mM}$ unlabeled IPP, $0.9 \mathrm{nmol}\left[{ }^{14} \mathrm{C}\right]-\mathrm{IPP}$ $\left(2 \times 10^{9} \mathrm{~Bq} / \mathrm{mmol}\right.$ specific activity of labeled IPP; final specific activity of the mixed IPP was $1.9 \times 10^{3} \mathrm{~Bq}$ per reaction), and $15 \mu \mathrm{M}$ of FPP in a buffer solution $(100 \mathrm{mM}$ Tris- $\mathrm{HCl}, \mathrm{pH} 7.5$, $1.25 \mathrm{mM} \mathrm{MgSO}_{4}, 5 \mathrm{mM}$ DTT) to a final volume of $40 \mu \mathrm{l}$. The reactions were performed in triplicate in a 96-well filter plate (Millipore, USA) for $4 \mathrm{~h}$ at $16{ }^{\circ} \mathrm{C}$, stopped by $40 \mathrm{mM}$ EDTA, and then washed twice with $\mathrm{H}_{2} \mathrm{O}$ and once with EtOH- $\mathrm{H}_{2} \mathrm{O}(95: 5, \mathrm{v} / \mathrm{v})$. The filter plate was oven-dried at $37^{\circ} \mathrm{C}$ for $30 \mathrm{~min}$ and then the amount of $\left[{ }^{14} \mathrm{C}\right]$-IPP in each individual filter was determined by scintillation counting (Beckman Coulter, USA). The concentration of rubber per sample was determined by the dry weight of material collected on the filter and used to normalize IPP incorporation.

\section{Disclaimer}

Mention of trade names or commercial products in this report is solely for the purpose of providing specific information and does not imply recommendation or endorsement by the U.S. Department of Agriculture.

\section{Acknowledgments}

This research was funded by the United States Department of Agriculture, Agricultural Research Service, CRIS Project \#532521410-020-00D. Development of cDNA libraries and EST sequencing was funded by the Nevada National Science Foundation Experimental Program to Stimulate Competitive Research (NSF-EPSCOR), and by NSF Plant Genome Research Program DBI-03211690. Contributions to preliminary experiments by Dr. Katrina Cornish (former USDA-ARS, now Ohio State University) are gratefully acknowledged. Researchers thank Grace Chen and Kent McCue for critical reading of the manuscript. USDA is an equal opportunity provider and employer.

\section{Appendix A. Supplementary data}

Supplementary data associated with this article can be found, in the online version, at http://dx.doi.org/10.1016/j.phytochem.2012. 04.007.

\section{References}

Alcazar, R., Altabella, T., Marco, F., Bortolotti, C., Reymond, M., Koncz, C., Carrasco, P., Tiburcio, A.F., 2010. Polyamines: molecules with regulatory functions in plant abiotic stress tolerance. Planta 231, 1237-1249.

Aoki, K., Suzui, N., Fujimaki, S., Dohmae, N., Yonekura-Sakakibara, K., Fujiwara, T. Hayashi, H., Yamaya, T., Sakakibara, H., 2005. Destination-selective longdistance movement of phloem proteins. Plant Cell 17, 1801-1814.

Asawatreratanakul, K., Zhang, Y.-W., Wititsuwannakul, D., Wititsuwannakul, R. Takahashi, S., Rattanapittayaporn, A., Koyama, T., 2003. Molecular cloning, expression and characterization of cDNA encoding cis-prenyltransferases from Hevea brasiliensis. A key factor participating in natural rubber biosynthesis. Eur. J. Biochem. 270, 4671-4680.

Ashburner, M., Ball, C.A., Blake, J.A., Botstein, D., Butler, H., Cherry, J.M., Davis, A.P., Dolinski, K., Dwight, S.S., Eppig, J.T., Harris, M.A., Hill, D.P., Issel-Tarver, L., Kasarskis, A., Lewis, S., Matese, J.C., Richardson, J.E., Ringwald, M., Rubin, G.M., Sherlock, G., 2000. Gene ontology: tool for the unification of biology. The Gene Ontology Consortium. Nat. Genet. 25, 25-29. 
Bach, T.J., 1986. Hydroxymethylglutaryl-CoA reductase, a key enzyme in phytosterol synthesis? Lipids 21, 82-88.

Backhaus, R.A., Cornish, K., Chen, S.-F., Huang, D.-S., Bess, V.H., 1991. Purification and characterization of an abundant rubber particle protein from guayule. Phytochemistry 30, 2493-2497.

Balbuena, T.S., Salas, J.J., Martínez-Force, E., Garcés, R., Thelen, J.J., 2011. Proteome analysis of cold acclimation in sunflower. J. Proteome Res. 10, 2330-2346.

Benedict, C.R., Greer, P., Foster, M.A., 2008. The physiology and biochemical responses of guayule to the low temperature of the Chihuahuan Desert in the biosynthesis of rubber. Ind. Crops Prod. 27, 225-235.

Benedict, C.R., Goss, R., Paul, J., Foster, M.A., 2010. The formation of rubberproducing cortical parenchyma cells in guayule (Parthenium argentatum Gray) by low temperature. Ind. Crops Prod. 31, 516-520.

Berkowitz, O., Jost, R., Pollmann, S., Masle, J., 2008. Characterization of TCTP, the translationally controlled tumor protein, from Arabidopsis thaliana. Plant Cell $20,3430-3447$.

Bonner, J., 1943. Effects of temperature on rubber accumulation by the guayule plant. Bot. Gaz. 105, 233-243.

Brioudes, F., Thierry, A.M., Chambrier, P., Mollereau, B., Bendahmane, M., 2010. Translationally controlled tumor protein is a conserved mitotic growth integrator in animals and plants. Proc. Natl. Acad. Sci. USA 107, 16384-16389.

Castillon, J., Cornish, K., 1999. Regulation of initiation and polymer molecular weight of cis-1,4-polyisoprene synthesized in vitro by particles isolated from Parthenium argentatum (Gray). Phytochemistry 51, 43-51.

Chappell, J., 1995. Biochemistry and molecular biology of the isoprenoid biosynthetic pathway in plants. Annu. Rev. Plant Physiol. Plant Mol. Biol. 46 521-547.

Chow, K.-S., Wan, K.-L., Mat Isa, M.N., Bahari, A., Tan, S.-H., Harikrishna, K., Yeang, H.-Y., 2007. Insights into rubber biosynthesis from transcriptome analysis of Hevea brasiliensis latex. Exp. Bot. 58, 2429-2440.

Chye, M.-L., Tan, C.-T., Chua, N.-H., 1992. Three genes encode 3-hydroxy-3methylglutaryl-coenzyme A reductase in Hevea brasiliensis: hmgs1 and hmgs3 are differentially expressed. Plant Mol. Biol. 19, 473-484.

Cornish, K., 2001. Similarities and differences in rubber biochemistry among plant species. Phytochemistry 57, 1123-1134.

Cornish, K., Backhaus, R.A., 1990. Rubber transferase activity in rubber particles of guayule. Phytochemistry 29, 3809-3813.

Cornish, K., Backhaus, R.A., 2003. Induction of rubber transferase activity in guayule (Parthenium argentatum Gray) by low temperatures. Ind. Crops Prod. 17, 83-92.

Cornish, K., Williams, J., Hall, J.L., McCoy, R.G., 2008. Production and properties of Yulex - the natural solution to latex allergy. Rubber Chem. Technol. 81, 709722.

Dai, Z., Cui, G., Zhou, S.-F., Zhang, X., Huang, L., 2011. Cloning and characterization of a novel 3-hydroxy-3-methylglutaryl coenzyme A reductase gene from Salvia miltiorrhiza involved in diterpenoid tashinone accumulation. J. Plant Physiol. 168, 148-157.

Dellagi, A., Birch, P.R.J., Helibronn, J., Avrova, A.O., Montesano, M., Tapio Palva, E., Lyon, G.D., 2000. A potato gene, erg-1, is rapidly induced by Erwinia carotovora ssp. atroseptica, Phytophthora infestans, ethylene and salicylic acid. J. Plant Physiol. 157, 201-205.

Demel, R.A., Dorrepaal, E., Ebskamp, M.J.M., Smeekens, J.C.M., de Kruijff, B., 1998 Fructans interact strongly with model membranes. Biochim. Biophys. Acta $1375,36-42$

Downes, R.W., Tonnet, M.L., 1985. Effect of environmental conditions on growth and rubber production of guayule (Parthenium argentatum). Aust. J. Agric. Res. 36, 285-294.

Ermolayev, V., Weschke, W., Manteuffel, R., 2003. Comparison of Al-induced gene expression in sensitive and tolerant soybean cultivars. J. Exp. Bot. 54, 27452756.

Ewing, B., Hillier, L., Wendl, M.C., Green, P., 1998. Base-calling of automated sequencer traces using Phred: I. Accuracy assessment. Genome Res. 8, 175-185.

Gomez, J.B., 1982. Anatomy of Hevea and Its Influence on Latex Production. Malaysian Rubber Research and Development Board, Kuala Lumpur

Goss, R.A., Benedict, C.R., Keithly, J.H., Nessler, C.L., Stipanovic, R.D., 1984. cisPolyisoprene synthesis in guayule plants (Parthenium argentatum Gray) exposed to low, nonfreezing temperatures. Plant Physiol. 74, 534-537.

Hamilton, R., Cornish, K., 2010. Immunogenicity studies of guayule and guayule latex in occupationally exposed workers. Ind. Crops Prod. 31, 197-201.

Han, K.-H., Shin, D.H., Yang, J., Kim, I.J., Oh, S.K., Chow, K.S., 2000. Genes expressed in the latex of Hevea brasiliensis. Tree Physiol. 20, 503-510.

Hughes, R.K., Belfield, E.J., Ashton, R., Fairhurst, S.A., Gobel, C., Stumpe, M., Feussner I., Casey, R., 2006. Allene oxide synthase from Arabidopsis thaliana (CYP74A1) exhibits dual specificity that is regulated by monomer-micelle association. FEBS Lett. 580, 4188-4194.

Hughes, R.K., De Domenico, S., Santino, A., 2009. Plant cytochrome CYP74 family: biochemical features, endocellular localisation, activation mechanism in plant defense and improvements for industrial applications. ChemBioChem 10, 1122 1133.

Jasso de Rodriguez, D., Angulo-Sanchez, J.L., Rodriquez-Garcia, R., 2006. Mexican high rubber producing guayule shrubs: a potential source for commercial development. J. Polym. Environ. 14, 37-47.

Ji, W., Benedict, C.R., Foster, M.A., 1993. Seasonal variation in rubber biosynthesis, 3 hydroxy-3-methylglutaryl-coenzyme A reductase, and rubber transferase activities in Parthenium argentatum in the Chihuahuan Desert. Plant Physiol. $103,535-542$.
Kelly, K.M., van Stadem, J., 1994. Carbohydrate production in guayule. S. Afr. J. Bot. 60, 193-198.

Kharel, Y., Koyama, T., 2003. Molecular analysis of cis-prenyl chain elongating enzymes. Nat. Prod. Rep. 20, 111-118.

Kharel, Y., Takahashi, S., Yamashita, S., Koyama, T., 2006. Manipulation of prenyl chain length determination mechanism of cis-prenyltransferases. FEBS 273, 647-657.

Kim, I.J., Ryu, S.B., Kwak, Y.S., Kang, H., 2004. A novel cDNA from Parthenium argentatum Gray enhances the rubber biosynthetic activity in vitro. J. Exp. Bot. $55,377-385$.

Kim, Y.E., Seo, Y.S., Lee, H., Kim, W.T., 2010. Constitutive expression of CaSRP1, a hot pepper small rubber particle protein homolog, resulted in fast growth and improved drought tolerance in transgenic Arabidopsis plants. Planta 232, 7183.

Ko, J.-H., Chow, K.-S., Han, K.-H., 2003. Transcriptome analysis reveal novel features of the molecular events occurring in the laticifers of Hevea brasiliensis (para rubber tree). Plant Mol. Biol. 53, 479-492.

Lynen, F., Henning, U., 1960. Biological path to natural rubber. Angew. Chem. 72.

Madhavan, S., Greenblatt, G.A., Foster, M.A., Benedict, C.R., 1989. Stimulation of isopentenyl pyrophosphate incorporation into polyisoprene in extracts from guayule plants (Parthenium argentatum Gray) by low temperature and 2-(3,4dichlorophenoxy) triethylamine. Plant Physiol. 89, 506-511.

Marrs, K.A., 1996. The functions and regulations of glutathione S-transferases in plants. Annu. Rev. Plant Physiol. Plant Mol. Biol. 47, 127-158.

Mau, C.J.D., Scott, D.J., Cornish, K., 2000. Multiwell filtration system results in rapid high-throughput rubber transferase microassay. Phytochem. Anal. 11, 356-361.

Mau, C.J.D., Garneau, S., Scholte, A.A., van Fleet, J.E., Vederas, J.C., Cornish, K., 2003. Protein farnesyltransferase inhibitors interfere with farnesyl diphosphate binding by rubber transferase. Eur. J. Biochem. 270, 3939-3945.

Maurel, C., Verdoucq, L., Luu, D.-T., Santoni, V., 2008. Plant aquaporins: membrane channels with multiple integrated functions. Annu. Rev. Plant Biol. 59, 595-624.

Mingeot, D., Dauchot, N., Van Cutsem, P., Watillon, B., 2009. Characterisation of two cold induced dehydrin genes from Cichorium intybus L.. Mol. Biol. Rep. 36, 19952001.

Nagegowda, D.A., Ramalingam, S., Hemmerlin, A., Bach, T.J., Chye, M.-L., 2005. Brassica junces HMG-CoA synthase: localization of mRNA and protein. Planta 221, 844-856.

Pan, Z., Durst, F., Werck-Reichhart, D., Gardner, H.W., Camara, B., Cornish, K., Backhaus, R.A., 1995. The major protein of guayule rubber particles is a cytochrome P450. Characterization based on cDNA cloning and spectroscopic analysis of the solubilized enzyme and its reaction products. J. Biol. Chem. 270, 8487-8494.

Pan, Z., Herickhoff, L., Backhaus, R.A., 1996. Cloning, characterization, and heterologous expression of cDNAs for farnesyl diphosphate synthase from the guayule rubber plant reveals that this prenyltransferase occurs in rubber particles. Arch. Biochem. Biophys. 332, 196-204.

Pfaffl, M.W., 2001. A new mathematical model for relative quantification in realtime RT-PCR. Nucleic Acids Res. 29, 2002-2007.

Pilon-Smits, E.A.H., Ebskamp, M.J.M., Paul, M.J., Jeuken, M.J.W., Weisbeek, P.J., Smeekens, S.C.M., 1995. Improved performance of transgenic fructanaccumulating tobacco under drought stress. Plant Physiol. 107, 125-130.

Polhamus, L.G., 1962. Rubber - botany, production, and utilization. World Crop Ser. 43.

Ritsema, T., Smeekens, S., 2003. Fructans: beneficial for plants and humans. Curr. Opin. Plant Biol. 6, 223-230.

Salvucci, M.E., Barta, C., Byers, J.A., Canarini, A., 2010. Photosynthesis and assimilate partitioning between carbohydrates and isoprenoid products in vegetatively active and dormant guayule: physiological and environmental constraints on rubber accumulation in a semiarid shrub. Physiol. Plant. 140, 368-379.

Sando, T., Takeno, S., Watanabe, N., Okumoto, H., Kuzuyama, T., Yamashita, A., Hattori, M., Ogasawara, N., Fukusaki, E., Kobayashi, A., 2008. Cloning and characterization of the 2-C-methyl-D-erythritol-4-phosphate (MEP) pathway genes of natural-rubber producing plant, Hevea brasiliensis. Biosci. Biotechnol. Biochem. 72, 2903-2917.

Sando, T., Hayashi, T., Takeda, T., Akiyama, Y., Nakazawa, Y., Fukusaki, E., Kobayashi, A., 2009. Histochemical study of detailed laticifer structure and rubber biosynthesis-related protein localization in Hevea brasiliensis using spectral confocal laser scanning microscopy. Planta 230, 215-225.

Schmidt, T., Hillebrand, A., Wurbs, D., Wahler, D., Lenders, M., Schulze Gronover, C., Prufer, D., 2010a. Molecular cloning and characterization of rubber biosynthetic genes from Taraxacum koksaghyz. Plant Mol. Biol. Rep. 28, 277-284.

Schmidt, T., Lenders, M., Hillebrand, A., van Deenen, N., Munt, O., Reichelt, R., Eisenreich, W., Fisher, R., Prufer, D., Schulze Gronover, C., 2010b. Characterization of rubber particles and rubber chain elongation in Taraxacum koksaghyz. BMC Biochem. 11, 1-11.

Siler, D.J., Cornish, K., 1993. A protein from Ficus elastica rubber particles is related to proteins from Hevea brasiliensis and Parthenium argentatum. Phytochemistry 32, 1097-1102.

Siler, D.J., Cornish, K., 1994a. Hypoallergenicity of guayule rubber particle proteins compared to Hevea latex proteins. Ind. Crops Prod. 2, 307-313.

Siler, D.J., Cornish, J., 1994b. Identification of Parthenium argentatum rubber particle proteins immunoprecipitated by an antibody that specifically inhibits rubber transferase activity. Phytochemistry 36, 623-627.

Siler, D.J., Cornish, K., Hamilton, R.G., 1996. Absence of cross-reactivity of igE antibodies from subjects allergic to Hevea brasiliensis latex with a new source of 
natural rubber latex from guayule (Parthenium argentatum). Allergy Clin. Immunol. 98, 895-902.

Siler, D.J., Goodrich-Tanrikulu, M., Cornish, K., Stafford, A.E., McKeon, T.A., 1997. Composition of rubber particles of Hevea brasiliensis, Parthenium argentatum, Ficus elastica, and Euphorbia lactiflua indicates unconventional surface structure. Plant Physiol. Biochem. 35, 881-889.

Singh, A.P., Wi, S.G., Chung, G.C., Kim, Y.S., Kang, H., 2003. The micromorphology and protein characterization of rubber particles in Ficus carica, Ficus benghalensis and Hevea brasiliensis. J. Exp. Bot. 54, 985-992.

Sirinupong, N., Suwanmanee, P., Doolittle, R.F., Suvachitanont, W., 2005. Molecular cloning of a new cDNA and expression of 3-hydroxy-3-methylglutaryl-CoA synthase gene from Hevea brasiliensis. Planta 221, 502-512.

Song, W.C., Brash, A.R., 1991. Purification of an allene oxide synthase and identification of the enzyme as a cytochrome P-450. Science 253, 781-784.

Sundar, D., Reddy, R., 2000. Low night temperature-induced changes in photosynthesis and rubber accumulation in guayule (Parthenium argentatum Gray). Photosynthetica 38, 421-427.

Suwanmanee, P., Sirinupong, N., Suvachittanont, W., 2004. Regulation of the expression of 3-hydroxy-3-methylglutaryl-CoA synthase gene in Hevea brasiliensis (B.H.K.) Mull. Arg.. Plant Sci. 166, 531-537.

Tanaka, Y., Aik-Hwee, E., Ohya, N., Nishiyama, N., Tangpakdee, J., Kawahara, S., Wititsuwannakul, R., 1996. Initiation of rubber biosynthesis in Hevea brasiliensis: characterization of initiating species by structural analysis. Phytochemistry 41, 1501-1505.

Tanaka, Y., 2001. Structural characterization of natural polyisoprenes: solve the mystery of natural rubber based on structural study. Rubber Chem. Technol. 74, 355-375.
Tungngoen, K., Viboonjun, U., Kongsawadworakul, P., Katsuhara, M., Julien, J.L., Sakr S., Chrestin, H., Narangajavana, J., 2010. Hormonal treatment of the bark of rubber trees (Hevea brasiliensis) increases latex yield through latex dilution in relation with the differential expression of two aquaporin genes. J. Plant Physiol. 168, 253-262.

van Beilen, J.B., Poirier, Y., 2007. Establishment of new crops for the production of natural rubber. Trends Biotechnol. 25, 522-529.

Veatch, M.E., Ray, D.T., Mau, C.J.D., Cornish, K., 2005. Growth, rubber, and resin evaluation of two-year old transgenic guayule. Ind. Crops Prod. 22, 65-74.

Veatch-Bolhm, M.E., Ray, D.T., Gehrels, A., 2007. Night temperature, rubber production, and carbon exchange in guayule. Ind. Crops Prod. 25, 34-43.

Venkatachalam, P. Thulaseedharan, A. Raghothama, K. 2007. Identification of expression profiles of tapping panes dryness (TDP) associated genes from the latex rubber tree (Hevea brasiliensis Muell. Arg.). Planta 226, 499-515.

Vereyken, I.J., Chupin, V., Demel, R.A., Smeekens, S.C.M., Kruijff, B.D., 2001. Fructans insert between the headgroups of phospholipids. Biochim. Biophys. Acta 1510, 307-320.

Whitworth, J.W., Whitehead, E.E., 1991. Guayule natural rubber: a technical publication with emphasis on recent findings. Guayule Administrative Management Committee and USDA Cooperative State Research Service.

Xie, W., McMahan, C.M., DeGraw, A.J., Distefano, M.D., Cornish, K., Whalen, M.C. Shintani, D.K., 2008. Initiation of rubber biosynthesis: in vivo comparisons of benzophenone-modified diphosphate analogues in three rubber-producing species. Phytochemistry 69, 2539-2545. 